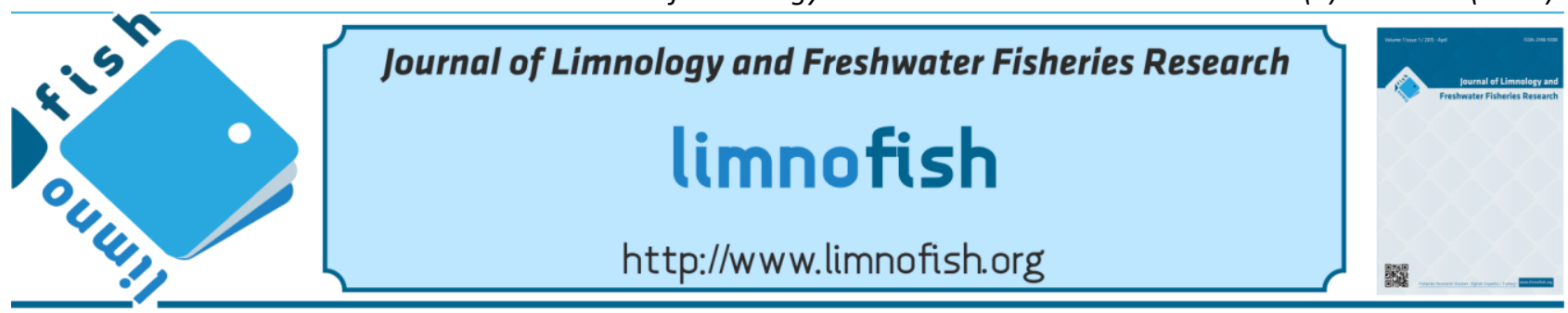

\title{
An Invasion Report of The New Zealand Mud Snail, Potamopyrgus antipodarum (Gray, 1843) in Turkish Freshwaters: Delice River and Kocabaş Stream
}

\author{
Serpil ODABAŞI ${ }^{1}$ (D), Naime ARSLAN² ${ }^{\mathbb{D}}$, Şükran Yalçın ÖZDILEK ${ }^{3}$ (D), Deniz Anıl ODABAŞI ${ }^{4 *}$ \\ ${ }^{1}$ Çanakkale Onsekiz Mart University, Vocational School of Marine Technologies, Department of Underwater Technology, \\ Çanakkale-Turkey. \\ ${ }^{2}$ Eskişehir Osmangazi University, Science and Art Faculty, Department of Biology, Eskişehir-Turkey. \\ ${ }^{3}$ Çanakkale Onsekiz Mart University, Science and Art Faculty, Department of Biology. Çanakkale-Turkey. \\ ${ }^{4}$ Çanakkale Onsekiz Mart University, Faculty of Marine Science and Technology, Marine and Inland Water Sciences. Çanakkale- \\ Turkey.
}

\section{A B STR ACT}

This study is combined the data from two different studies that carried out different regions and time, presenting some information on the population structure (dominance, local distribution etc.) of Potamopyrgus antipodarum (Gray, 1843). According to our data, this species was found in the four different localities in the Delice River with various population densities. However, only of small population was found in the Kocabaş Stream. This species was the second dominant species in the Delice River with $31.43 \%$ after Physella acuta (Draparnaud, 1805) (46.88\%). On the other hand, the species was not reached noticeable aggregates in the Kocabas Stream. In this paper, supporting factors that paving the way $P$. antipodarum invasion are discussed for the study area.

Keywords: Potamopyrgus antipodarum, invasive population, Delice River, Kocabaş Stream, Turkey

\section{ARTICLE INFO}

\section{RESEARCH ARTICLE}

Received : 22.11 .2018

Revised : 25.03.2019

Accepted : :28.03.2019

Published : :25.12.2019

DOI:10.17216/LimnoFish.486626

\section{* CORRESPONDING AUTHOR}

aodabasi@comu.edu.tr

Phone : +902862180018

Türkiye içsularında Yeni Zelanda Çamur Salyangozu, Potamopyrgus antipodarum (Gray, 1843)'un bir istila raporu: Delice Nehri ve Kocabaş Çayı

Öz: İki farklı bölgede ve zamanda yürütülen çalışmalardan elde edilen verileri kapsayan bu çalışma, Potamopyrgus antipodarum (Gray, 1843)'un popülasyon yapısı ile ilgili bazı verileri (baskınlık, bölgedeki dağılımı gibi) sunmaktadır. Verilerimize göre, Delice Nehri'nde $P$. antipodarum dört farklı noktada ve farklı populasyon yoğunluklarında tespit edilmiştir. Ancak Kocabaş Çayı'nda sadece küçük bir populasyonun varlığına rastlanmıştır. Bu tür \% 31,43 değeri ile Delice Nehri'nde Physella acuta (Draparnaud, $1805)$ 'dan $(\% 46,88)$ sonra ikinci en baskın türdür. Diğer taraftan, bu tür Kocabaş Çayı'nda çok yüksek sayıda bir popülasyona sahip değildir. Bu makalede, $P$. antipodarum'un istilasını destekleyen faktörler tartışılmıştır.

Anahtar kelimeler: Potamopyrgus antipodarum, istilacı populasyon, Delice Nehri, Kocabaş Çayı, Türkiye

How to Cite

Odabaşı S, Arslan N, Yalçın Özdilek Ş, Odabaşı DA. 2019. An Invasion report of The New Zealand Mud Snail (Potamopyrgus antipodarum Gray, $1843)$ in Turkish Freshwaters: Delice River and Kocabaş Stream. LimnoFish. 5(3): 213-219. doi: 10.17216/LimnoFish.486626

\section{Introduction}

The New Zealand mud snail, Potamopyrgus antipodarum (Gray, 1843), is a truncatelloidean gastropod that can be able to tolerate a wide range of abiotic conditions from coastal estuaries to freshwater ecosystems (Gérard et al. 2003). It is known as an invasive worldwide that the current expansion comprises several continents including Europe, mainland Australia and Tasmania (Ponder 1988) and North America (Bowler 1991).
According to Ponder (1988), introduction of this species date back to $19^{\text {th }}$ century in southern Australia, Tasmania and Europe, then the species has been reported in North America in 1987 (Bowler 1991), Japan (Shimada and Urabe 2003), and more recently in Canada (Davidson et al. 2008). Shell remains of the species have also been found in Lebanon and Iraq (Naser and Son 2009). In Turkey, occurrence of $P$. antipodarum has been known from various freshwater ecosystems and only one coastal 
marine area in the western and southern Anatolia since 1980 (Bilgin 1980; Ustaoğlu et al. 2001a, b; Ustaoğlu et al. 2003; Özbek et al. 2004; Kalyoncu et al. 2008; Kılıçarslan and Özbek 2010; Yıldırım et al. 2006; Kebapçı and Yıldırım 2010; Gürlek 2015; Odabaşı and Arslan 2015). Although, its global spread and high infestation rate, all the documentations rely on several shells or specimens and the present records are not related with its population and invasion status on their habitats in Turkey. In this study, we have combined the data sets of two different studies carried out in different running waters: Delice (a branch of the River Kız1lırmak) and Kocabaş (running water located in Biga Peninsula), which are located in central and north-western Anatolia, respectively. This study aimed to evaluate the mollusc fauna and demonstrate the population structures of $P$. antipodarum inhabiting in these streams, we also evaluated the invasive characteristics of this species in studied areas.

\section{Materials and Methods}

Study Area

The first study area is Delice River that is one of the major tributaries of the Kizılırmak River which is the longest running water across Turkey. The Kizilirmak River flows for a total of $1355 \mathrm{~km}$, rising from Eastern Anatolia and flows into the Black Sea. The Delice River, one of the main tributaries of the Kizllirmak River, flows along $430 \mathrm{~km}$ with a high flow rate approximately $30352 \mathrm{~m}^{3} / \mathrm{s}$ annually. It has many small tributaries while passing through the Çankırı, Yozgat, Kırşehir and Kirkkale cities before the joining to the Kizılırmak River (Gül and Y1lmaz 2002). Samplings were carried out monthly between July 2007 and August 2008 in the preselected sampling sites in Delice River.

On the other hand, the second study area is Kocabaş Stream (also called as Biga Stream) that rising from the extension of the Kaz Mountain, the ancient name is known as Mount Ida, flows into the Sea of Marmara at Dardanelles. It is one of the most important watercourses in the Biga Peninsula with an $80 \mathrm{~km}$ in length and $30 \mathrm{~m}^{3} / \mathrm{s}$ annual flow rate. Seasonal samplings were carried out between May 2012 and November 2013 at two sites located both at the upper and lower regions of the dam lake in the Kocabaş Stream (Table 1).

Table 1. Species Content of the freshwater Mollusca in the study area both Delice River and Kocabaş Stream. Legends: St.: Sampling Station, S: Status, N: Native, NC: Non-Native - Cosmopolitan.

\begin{tabular}{|c|c|c|c|c|c|c|c|c|c|c|c|c|c|}
\hline & \multicolumn{10}{|c|}{ Delice River } & \multicolumn{3}{|c|}{ Kocabaş Stream } \\
\hline & $\begin{array}{c}\text { St. } \\
1\end{array}$ & $\begin{array}{c}\text { St. } \\
2\end{array}$ & $\begin{array}{c}\text { St. } \\
3\end{array}$ & $\begin{array}{c}\text { St. } \\
4\end{array}$ & $\begin{array}{c}\text { St. } \\
5\end{array}$ & $\begin{array}{c}\text { St. } \\
6\end{array}$ & $\begin{array}{c}\text { St. } \\
7\end{array}$ & $\begin{array}{c}\text { St. } \\
8\end{array}$ & $\begin{array}{c}\text { St. } \\
9\end{array}$ & $\begin{array}{l}\text { St. } \\
10\end{array}$ & Downstream & Upstream & $\mathbf{S}$ \\
\hline Borystenia naticina & & & & + & & & & & & & & & $\mathrm{N}$ \\
\hline Valvata kebapcii & & & & + & & & & + & + & & & & $\mathrm{N}$ \\
\hline P. antipodarum & + & & & + & + & & & + & & & + & & $\mathrm{NC}$ \\
\hline Pseudamnicola natolica & + & & & & + & & & & & & & & $\mathrm{N}$ \\
\hline Theodoxus fluviatilis & + & & & & & & & & & & & & $\mathrm{N}$ \\
\hline Ancylus fluviatilis & & & & & & & & & & & & + & $\mathrm{N}$ \\
\hline Galba truncatula & & & & & + & & & & & & & & $\mathrm{N}$ \\
\hline Physella acuta & + & & & + & + & + & & + & + & + & & + & $\mathrm{NC}$ \\
\hline Radix labiata & + & & & & + & & & + & + & + & & & $\mathrm{N}$ \\
\hline Gyraulus piscinarum & + & & & + & + & & & + & + & & & + & $\mathrm{N}$ \\
\hline Dreissena polymorpha & + & & & & & & & & & & & & $\mathrm{N}$ \\
\hline Musculium lacustre & & & & & & & & & & & & + & $\mathrm{N}$ \\
\hline Euglesa casertana & + & & & & & & & & & & & & $\mathrm{NC}$ \\
\hline Pisidium subtruncatum & & & & + & & & & & & + & & & $\mathrm{N}$ \\
\hline Sphaerium sp. & & & & + & & & & & & & & & $\mathrm{N}$ \\
\hline
\end{tabular}

Benthic samples were collected with a surber net from the different habitats in the stream including aquatic vegetation, stone-gravel, and sand. The samples were sieved with a series of strainer mesh sizes of $1,0.5$ and $0.25 \mathrm{~mm}$, and then the snails were put into $75 \%$ lab-grade ethanol in the field. Individuals counted one by one under stereo microscope to determine density in a unit area. A random sub-sampling was performed for shell measurements including shell height $(\mathrm{SH})$, shell 
width (SW) according to Glöer (2015). Shell measurements carried out by means of imaging system consisting of stereo microscope (Stemi 508, Zeiss) and a camera (Axiocam 105 color). At least 26 snails were included to measurements by sub-sampling. We also inspected to brood pouch contents of the sub-sampled snails in order to reveal seasonal reproductive efficiency. Randomly 15 snails per sub-sample unit were inspected for brood pouch regardless of their size.

\section{Results and Discussion}

Mollusca fauna and population structure of invasive species, $P$. antipodarum, inhabiting in two distinct areas were evaluated. Results showed that 12 and 5 taxa inhabiting in the Delice River and Kocabaş Streams respectively (Table 2, 3). The members of Mollusca fauna were assessed as nativeand non-native. There are 12 native and 3 nonnative species were recorded in the two study areas (Table 1).

Potamopyrgus antipodarum originated from The New Zealand and Physella acuta, North American origin, are known as global invaders (Dillon et al. 2002; Semenchenko et al. 2008), so we can describe them as a non-native one in this study. In the stations of Delice River, a population with a higher number of individuals was detected (Figure 1, Table 2).

Table 2. Individual numbers per square meter of Mollusca found in the sampling stations (St.) of the Delice River.

\begin{tabular}{llllllll}
\hline Individual numbers & St. 1 & St. 4 & St. 5 & St. 6 & St. 8 & St. 9 & St. 10 \\
\hline Borystenia naticina & 0 & 44 & 0 & 0 & 0 & 0 & 0 \\
Valvata kebapcii & 0 & 222 & 0 & 0 & 88 & 44 & 0 \\
Potamopyrgus antipodarum & 677144 & 44 & 133 & 0 & 89 & 0 & 0 \\
Pseudamnicola natolica & 44 & 0 & 88 & 0 & 0 & 0 & 0 \\
Theodoxus fluviatilis & 1909 & 0 & 0 & 0 & 0 & 0 & 0 \\
Galba truncatula & 0 & 0 & 1909 & 0 & 0 & 0 & 0 \\
Physella acuta & 16561 & 89 & 12318 & 14340 & 133 & 18958 & 44 \\
Radix labiata & 44 & 0 & 177 & 0 & 44 & 177 & 443 \\
Gyraulus piscinarum & 177 & 133 & 44 & 0 & 44 & 44 & 0 \\
Dreissena polymorpha & 44 & 0 & 0 & 0 & 0 & 0 & 0 \\
Euglesa casertana & 133 & 0 & 0 & 0 & 0 & 0 & 0 \\
Pisidium subtruncatum & 0 & 266 & 0 & 0 & 0 & 0 & 177 \\
Sphaerium sp. & 0 & 44 & 0 & 0 & 0 & 0 & 0 \\
\hline
\end{tabular}

Table 3. Individual numbers per square meter of Mollusca found in Kocabaş Stream

\begin{tabular}{lll}
\hline Individual numbers & Lw* & Up* \\
\hline Potamopyrgus antipodarum & 142 & 0 \\
Ancylus fluviatilis & 0 & 44 \\
Physella acuta & 0 & 22 \\
Gyraulus piscinarum & 0 & 22 \\
Musculum lacustre & 0 & 22 \\
\hline
\end{tabular}

Lw: Lower part of the dam lake, Up: Upper part of the dam lake.

According to the community parameters in the Delice River, $P$. antipodarum predominated over the other mollusca taxa in the sampling site 1 (St. 1) (Figure 1). It has reached of the densest population in St. 1 with $56429 / \mathrm{m}^{2}$ (Table 2). Among the sampling stations of the Delice River including $4^{\text {th }}, 5^{\text {th }}$ and $8^{\text {th }}, P$. antipodarum rarely established with a sparsely population (Table 2).

On the other hand, P. antipodarum was sampled from only one sampling site (lower dam Lake of Bakacak) with a few numbers of individuals $\left(142 / \mathrm{m}^{2}\right)$ but predominated over associated species in Kocabaş Stream (Figure 4, Table 3). 


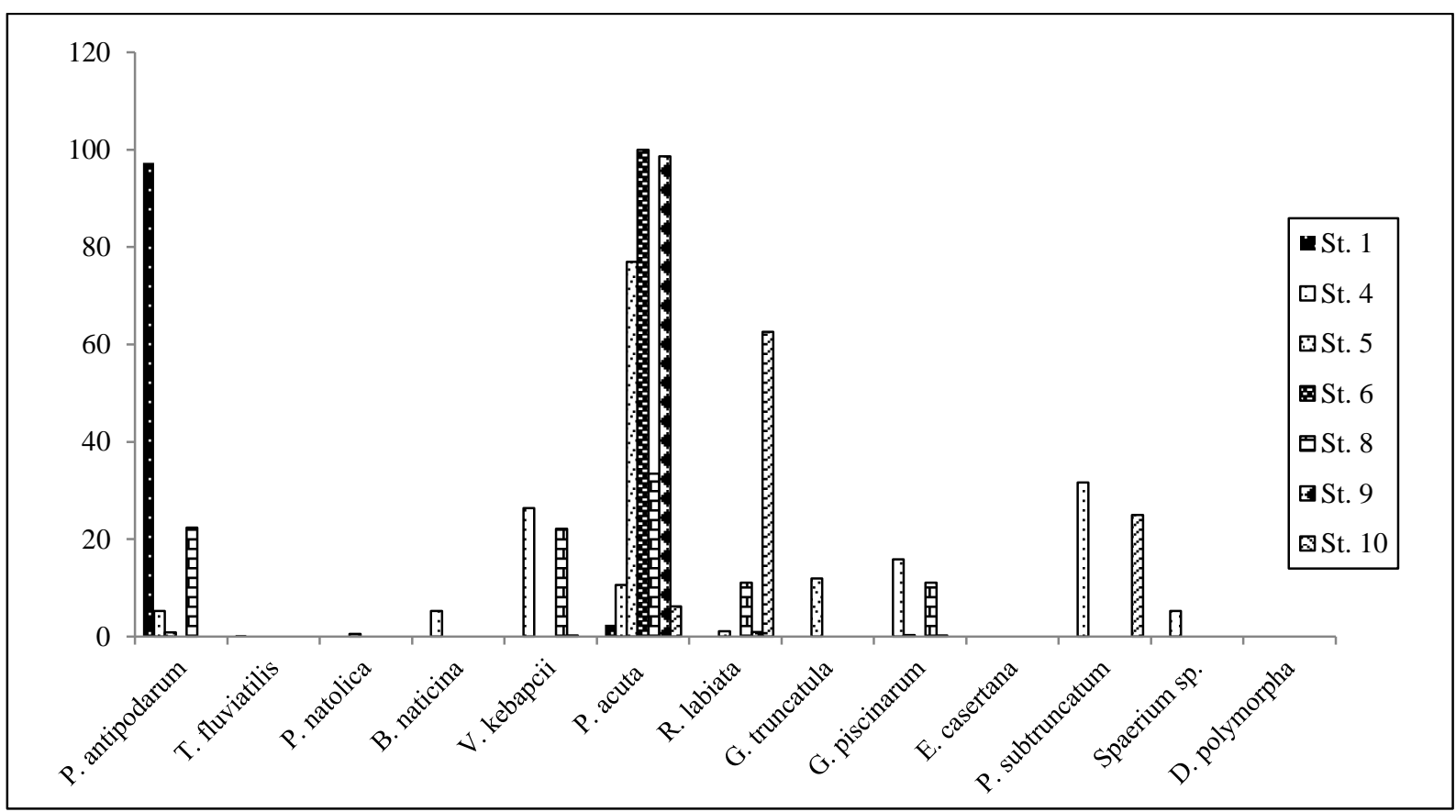

Figure 1. Dominance percentage of the Mollusca in the stations of the Delice River.

Considering the habitat structure and characteristics of the stations in which inhabiting of a $P$. antipodarum population in the study area, in the Delice River, the first station can be placed into a distinguished position among others as it is mainly fed by groundwater springs from the bottom (personal observation). Theodoxus fluviatilis and Pseudamnicola natolica are associated taxa with $P$. antipodarum supporting this claim because of their special habitat preference; springs (rheocrenes) and groundwater inhabitants (Yildırım 1999; Falkner et al. 2001) that indicating the groundwater sources in the sampling region. According to the data, $P$. antipodarum might be considered as invasive for the region ( $1^{\text {st }}$ station of the Delice River) due to a well-established population. Owing to the constant water quality regime throughout the year occurring in the spring-fed streams, they are suitable for growthof introduced species. The report of Hamada et al. (2013) also supports our findings that hot spring discharges are suitable habitats of $P$. antipodarum in Japan.

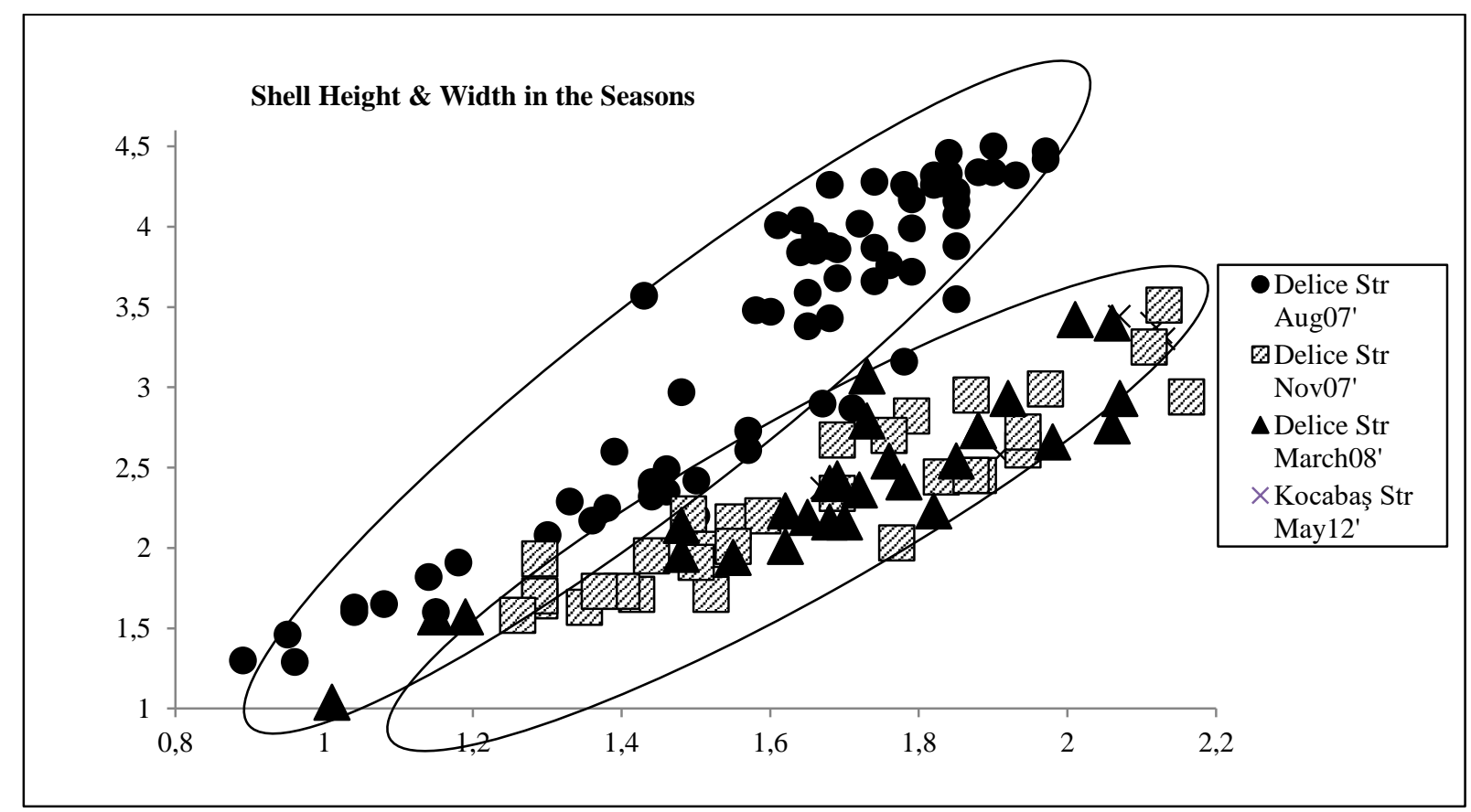


Figure 2. Seasonal shell height and shell width distributions of $P$. antipodarum in Delice River and Kocabaş Stream.

Shell height (SH) and width (SW) distributions of $P$. antipodarum revealed for streams in different seasons (Figure 2). As can be seen in the diagram, higher shells of $P$. antipodarum were observed in the
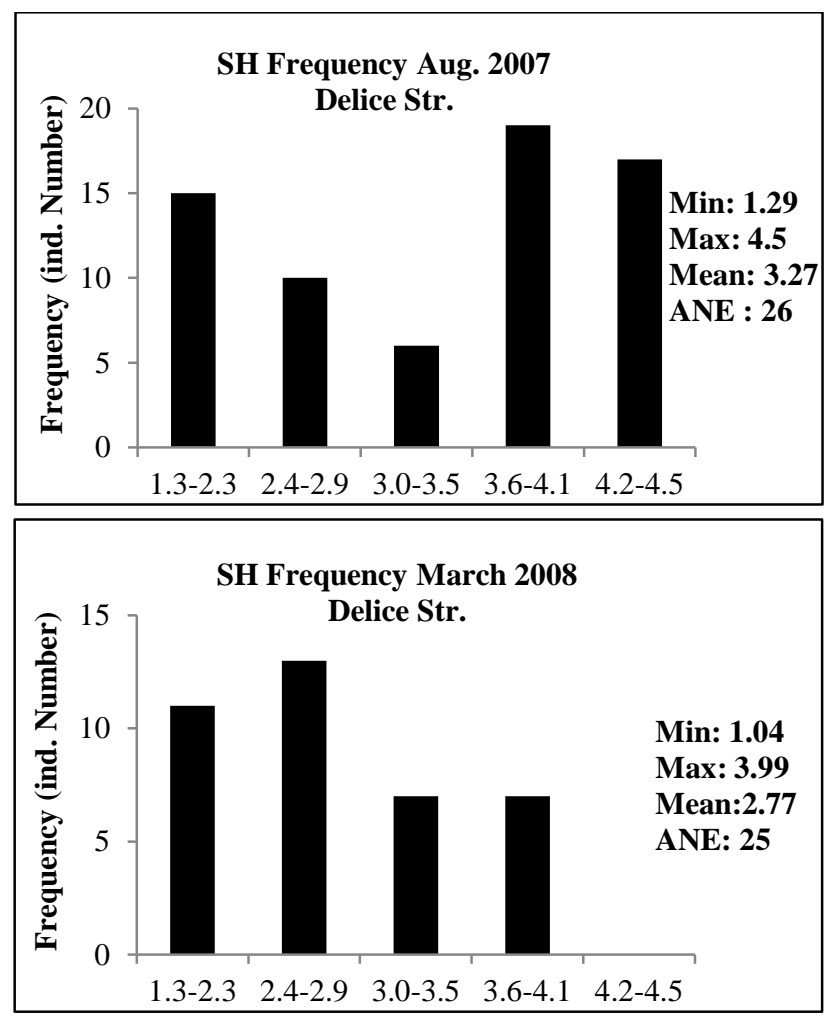

season August 2007 in Delice River (Figure 2). Other seasons' SH and SW distributions of $P$. antipodarum belong to the streams were overlapped.

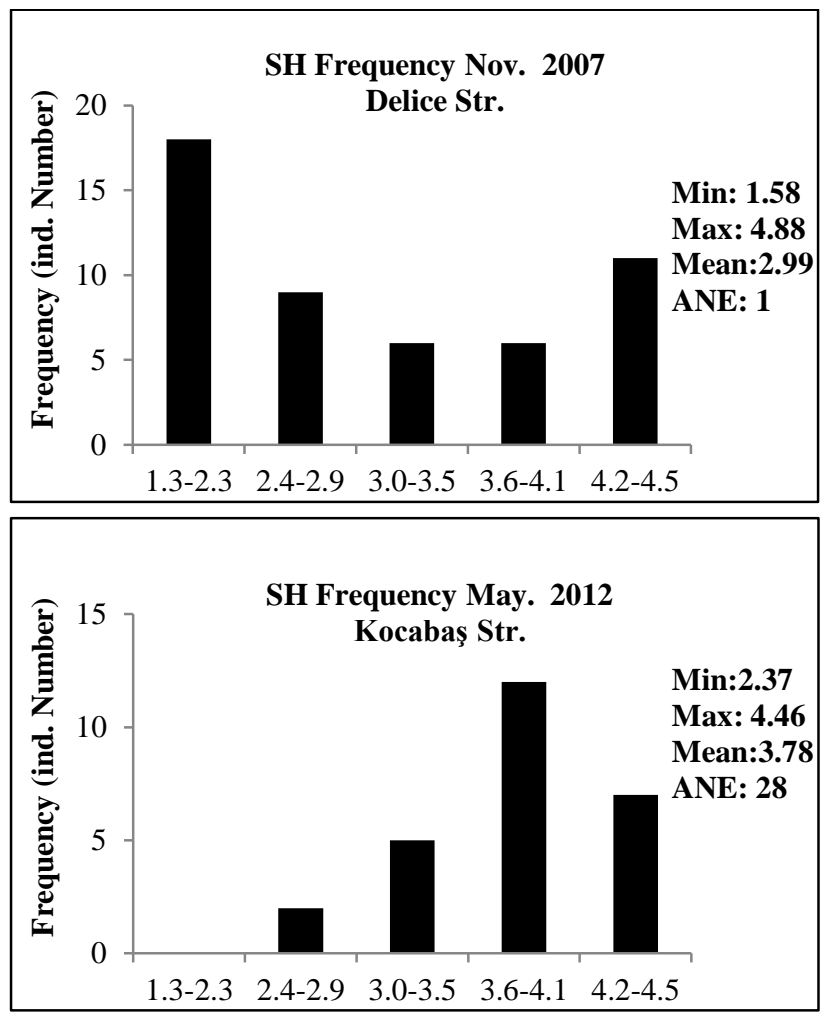

Figure 3. Seasonal shell height frequencies with maximum, minimum, mean values and the average number of embryo (ANE) of P. antipodarum in Delice River and Kocabaş Stream.

Snails were grouped into five $\mathrm{SH}$ ranges between minimum of $1.3 \mathrm{~mm}$ and maximum 4.5. Similar to SH distributions, higher frequency of appearance of longer shells were detected in the August 2007 of Delice River. On the contrary, the smaller SH ranges of shells assembled in the months March, May, and November, which are representing spring and autumn seasons. Minimum and maximum SH (mm) values, as expected, were in March and August 2007 respectively. Appearance frequency of the $\mathrm{SH}$ groups might be indicating that reproduction and individual growing occurred in seasons. Our data showed an annual life cycle for the seasons except winter. Accordingly, the first group range of the population, it can be considered as juveniles, were dominant group in November 2007 and March 2008 while the adults that can be placed into the last two SH groups were higher in number in August 2007. Although the sampling at the Kocabass Stream coincided in early summer, growing population is visible by rising numbers of adult groups. As can be seen in charts, average number of embryo production was interrupted at Delice River only in November 2007
(Figure 3, ANE). The most productive season was early summer (in Kocabaş Stream) and summer (in Delice River). According to the brood pouch inspection, the minimum size of reproductive maturity was $3.47 \mathrm{~mm}$ in $\mathrm{SH}$ and $1.6 \mathrm{~mm}$ in SW bearing 21 embryos and neonates (Figure 3).

Dorgelo et al. (2014), revealed the dynamics of $P$. antipodarum populations inhabiting in two different lakes which have different trophic levels. The study showed that size distributions followed a regular annual pattern in the eutrophic lake. In this study, similar to our findings, smaller individuals that made a dense contribution to population size in one season, increased larger shells in the next season as reducing the number of smaller individuals. According to pouch analysis, embryo and neonates production was interrupted between November and February. Taking into account of the reproduction time and first reproduction maturity, a close similarity is observed with our study.

Before a species invade to an ecosystem, it has to overcome several challenges (Kolar and Lodge 2001; Sakai et al. 2001; Alonso and Castro-Díez 2008). 
After the introduction of the species to a new environment, it must survive, grow and reproduce under the new environmental conditions (establishment). Furthermore, it must compete with the other organisms especially their ecologically similar taxa in order to reach a high population growth rate (invasion or spread). After that, the exotic species must alter the structure and functioning of the occupied ecosystem (impact) (Parker et al. 1999). In our study, as can be seen in Figure 1, P. antipodarum is successfully colonized at the $1^{\text {st }}$ station of Delice River with an enormous number of individuals dominating the native mollusk community. Thus, there is a possible risk of impact on the native ecosystem in this site due to establishment success of the invader. Besides, $P$. acuta predominated over existing taxa at the other sites of Delice River. When we consider two non-native invaders, it is obvious that $P$. antipodarum is predominating $P$. acuta at the $1^{\text {st }}$ station of Delice River. In Kocabaş Stream, there is no certain evidence about invasion processes of $P$. antipodarum. However, the species seems to reach an establishment success in the lower part of the Bakacak Dam in Kocabaş Stream (Figure 4).

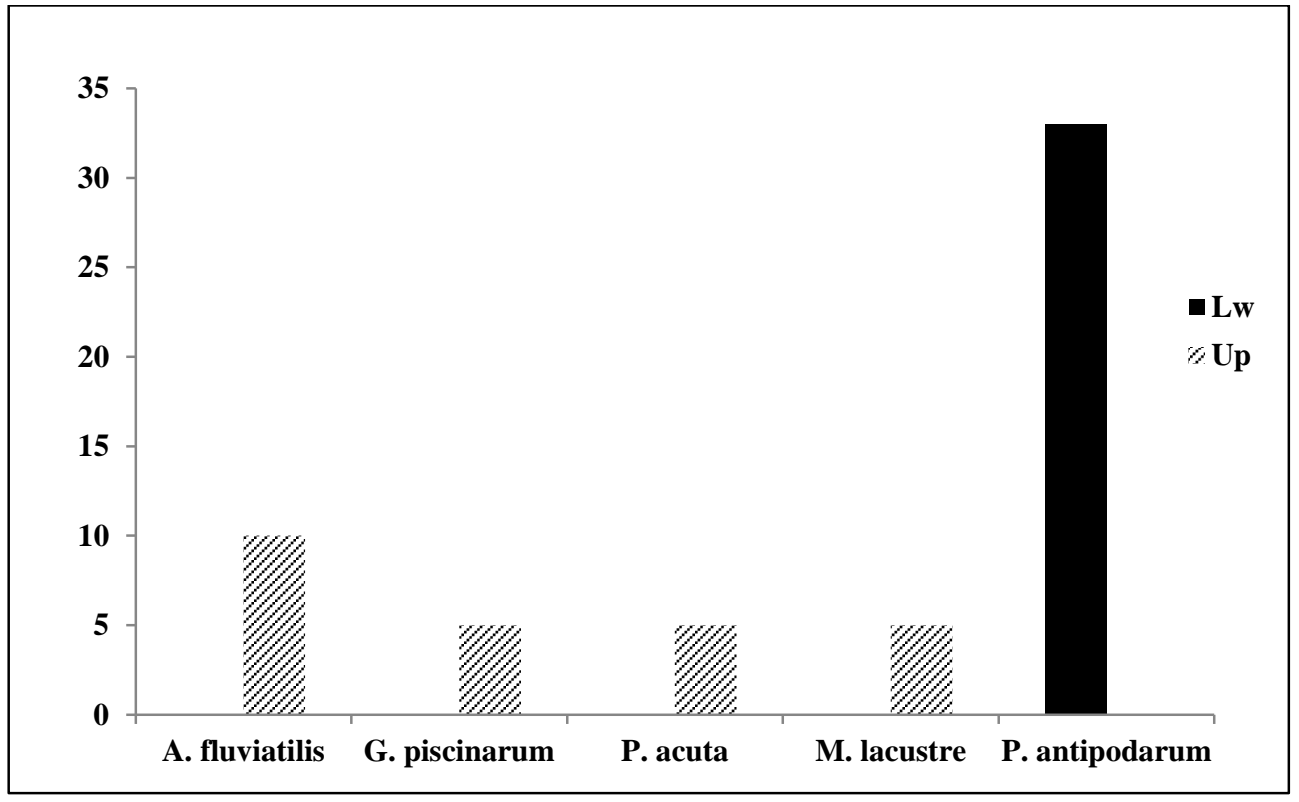

Figure 4. Dominance percentage of the Mollusca in the lower (Lw) and upper parts of the Dam Lake on the Kocabaş Stream.

In conclusion, further investigations and monitoring programs should be applied in order to clarify the influence of this non-native species on structure and functional ecology of the native benthic community.

\section{Acknowledgements}

In this study we have combined the data of two different projects supported by The Scientific and Technological Research Council of Turkey-TUBITAK coded 111 Y280 and Scientific Research Project Fund of Hacettepe University coded 0701601006 and was presented in Workshop on Risk Assessment Tools in Aquatic Species, 28-29 Nisan 2016, Düzce-Turkey by an oral presentation. We also would like to express our special thanks to two anonymous reviewers for their useful suggestions.

\section{References}

Alonso A, Castro-Díez P. 2008. What explains the invading success of the aquatic mud snail
Potamopyrgus antipodarum (Hydrobiidae, Mollusca)? Hydrobiologia. 614(1):107-116. doi: 10.1007/s10750-008-9529-3

Bilgin F. 1980. Batı Anadolu'nun bazı önemli tatl sularından toplanan Mollusca türlerinin sistematiği ve dağılışı. T.C. Diyarbakır Üniversitesi Tıp Fakültesi Dergisi Supplement 8(2):1-64.

Bowler P. 1991. The rapid spread of the freshwater hydrobiid snail Potamopyrgus antipodarum (Gray) in the middle Snake Stream, southern Idaho. Proceedings of the Desert Fishes Council. 21:173-182.

Davidson TM, Brenneis VEF, Rivera de C, Draheim R, Gillespie GE. 2008. Northern range expansion and coastal occurrences of the New Zealand mud snail Potamopyrgus antipodarum (Gray, 1843) in the northeast Pacific. Aquat Invasions. 3(3):349-353. doi: 10.3391/ai.2008.3.3.12

Dillon RT, Wethington AR, Rhett JM, Smith TP. 2002. Populations of the European freshwater pulmonate Physella acuta are not reproductively isolated from American Physella heterostropha or Physella integra. Invertebr Biol. 121(3):226-234. doi: 10.1111/j.1744-7410.2002.tb00062.x 
Dorgelo J, Harm GG, Hunting ER. 2014. Dynamics of natural populations of the dertitivorous mudsnail Potamopyrgus antipodarum (Gray) (Hydrobiidae) in two interconnected Lakes differing in trophic state. SpringerPlus. 3:736. doi: 10.1186/2193-1801-3-736

Falkner G, Obrdlík P, Castella E, Speight MCD. 2001. Shelled Gastropoda of Western Europe. München: Friedrich-Held-Gesellschaft 267 p.

Gérard C, Blanc A, Costil K. 2003. Potamopyrgus antipodarum (Mollusca: Hydrobiidae) in continental aquatic gastropod communities: impact of salinity and trematode parasitism. Hydrobiologia. 493(1-3):167-172. doi:10.1023/A:1025443910836

Glöer P. 2015. Süsswassermollusken: Ein Bestimmungsschlüssel für die Muscheln und Schnecken im Süßwasser der Bundesrepublik Deutschland. Germany: Hetlingen 135 p.

Gül A, Yılmaz M. 2002. Kizılırmak Nehri Delice Irmağı"nda Yaşayan Leuciscus cephalus (L., 1758)'un Büyüme Özellikleri. Gazi Üniversitesi Fen Bilimleri Enstitüsü Dergisi. 15(2):485-494.

Gürlek ME. 2015. Present distribution and a new locality record of the invasive freshwater mud snail Potamopyrgus antipodarum (Gray, 1843) (Gastropoda: Tateidae) in Turkey. Ecologica Montenegrina. 2(3):191-193.

Hamada K, Takeda N, Tatara Y, Ogata D, Nakajima M, Sonohara T, Urabe M. 2013. Habitat Desription of Potamopyrgus antipodarum (Caenogastropoda: Hydrobiidae) in Some Areas of Japan: How Far Will It Spread). Venus. 71(1-2):61-79. doi: 10.18941/venus.71.1-2_61

Kalyoncu H, Barlas M, Yildırım MZ, Yorulmaz B. 2008. Gastropods of two important streams of Gökova bay (Muğla, Turkey) and their relationships with water quality. International Journal of Science \& Technology. 3(1):27-36.

Kebapçı Ü, Yıldırım MZ. 2010. Freshwater snails fauna of lakes region (Göller Bölgesi), Turkey. Muzeul Olteniei Craiova. Oltenia. Studii şi comunicari. Ştiintele Naturii. 26(2):75-83.

Kilıçarslan I, Özbek M. 2010. Contributions to the knowledge on the distribution of freshwater Mollusca species of Turkey. Review of Hydrobiology. 3(2):127-144.

Kolar CS, Lodge DM. 2001. Progress in invasion biology: predicting invaders. Trends Ecol Evol. 16(4):199-204. doi: 10.1016/S0169-5347(01)02101-2

Naser MD, Son MO. 2009. First record of the New Zealand mud snail Potamopyrgus antipodarum (Gray 1843) from Iraq: the start of expansion to Western Asia? Aquat Invasions. 4(2):369-372. doi: 10.3391/ai.2009.4.2.11

Odabaşı DA, Arslan N. 2015. A New Species of Bithynia (Gastropoda: Bithyniidae) from an Eutrophic Lake Uluabat (South Marmara Region), Northwest of Turkey. Turkish Journal Of Fisheries And Aquatic Sciences. 15:371-375. doi: 10.4194/1303-2712-v15_2_20

Özbek M, Gökoğlu M, Ustaoğlu MR, Sarı HM. 2004. Kirkgöz (Antalya)'ün tatlısu Mollusca faunası. Paper presented at: Ulusal Su Günleri 2004; İzmir, Turkey.

Parker IM, Simberloff D, Lonsdale WM, Goodell K, Wonham M, Kareiva PM, Williamson MH, Von Holle B, Moyle PB, Byers JE, Goldwasser L. 1999. Impact: toward a framework for understanding the ecological effects of invaders. Biol Invasions. 1(1):3-19. doi: 10.1023/A:1010034312781

Ponder WF. 1988. Potamopyrgus antipodarum-a molluscan coloniser of Europe and Australia. J Mollus Stud.54(3):271-285

doi: 10.1093/mollus/54.3.271

Sakai AK, Allendorf FW, Holt JS, Lodge DM, Molofsky J, With KA, Baughman S, Cabin RJ, Cohen JE, Ellstrand NC, McCauley DE, O'Neil P, Parker IM, Thomp JN, Weller SG. 2001. The population biology of invasive species. Annu Rev Ecol Syst. 32:305-332.

doi: 10.1146/annurev.ecolsys.32.081501.114037

Semenchenko V, Laenko T, Razlutskij V. 2008. A new record of the North American gastropod Physella acuta (Draparnaud, 1805) from the Neman Stream Basin, Belarus. Aquatic Invasions. 3(3):359-360 doi: 10.3391/ai.2008.3.3.14

Shimada K, Urabe M. 2003. Comparative ecology of the alien freshwater snail Potamopyrgus antipodarum and the indigenous snail Semisulcospira spp. Venus. 62:39-53.

Ustaoğlu MR, Balık S, Özbek M. 2001a. Gediz Deltası ve Sazlıgöl (Menemen-İzmir)'ün tatlısu Mollusk faunas1. Paper presented at: XI. Ulusal Su Ürünleri Symposium; Hatay, Turkey.

Ustaoğlu MR, Balık S, Özbek M. 2001b. The Mollusc Fauna of Lake Işıklı (Çivril-Denizli). Ege University Journal of Fisheries \& Aquatic Sciences. 18(1-2):135-139.

Ustaoğlu MR, Balık S, Özbek M. 2003. The mollusca fauna of Yuvarlakçay (Köyceğiz, Muğla). Ege University Journal of Fisheries \& Aquatic Sciences. 20(3-4):433-438. doi: 10.12714/egejfas.2003.20.3.5000157096

Yildırım MZ. 1999. The Prosobranchia (Gastropoda: Mollusca) Species of Turkey and Their Zoogeographic Distribution 1. Fresh and Brackish Water. Turkish Journal of Zoology. 23(3):877-900.

Yıldırım MZ, Koca Bahadır S, Kebapçı Ü. 2006. Supplement to the Prosobranchia (Mollusca: Gastropoda) Fauna of Freshwater and Brackish Waters of Turkey. Turkish Journal of Zoology. 30:197-207. 